\title{
Effect of Light Intensity and Quality on Growth Rate and Composition of Chlorella vulgaris
}

\author{
Maria N. Metsoviti ${ }^{1} \oplus$, George Papapolymerou ${ }^{2}$, Ioannis T. Karapanagiotidis ${ }^{3}$ and \\ Nikolaos Katsoulas ${ }^{1, *(D)}$ \\ 1 Laboratory of Agricultural Constructions and Environmental Control, Department of Agriculture Crop \\ Production and Rural Environment, University of Thessaly, Fytokou Street, 38446 Volos, Greece; \\ mametsov@uth.gr \\ 2 Department of Environmental Sciences, University of Thessaly, 41110 Larissa, Greece; papapoly@teilar.gr \\ 3 Aquaculture Laboratory, Department of Ichthyology and Aquatic Environment, University of Thessaly, \\ Fytokou Street, 38446 Volos, Greece; ikarapan@uth.gr \\ * Correspondence: nkatsoul@uth.gr; Tel.: +30-24210-93249; Fax: +30-24210-93144
}

Received: 4 November 2019; Accepted: 23 December 2019; Published: 24 December 2019

check for updates

\begin{abstract}
In this research, the effect of solar irradiance on Chlorella vulgaris cultivated in open bioreactors under greenhouse conditions was investigated, as well as of ratio of light intensity in the $420-520 \mathrm{~nm}$ range to light in the $580-680 \mathrm{~nm}$ range $\left(\mathrm{I}_{420-520} / \mathrm{I}_{580-680}\right)$ and of artificial irradiation provided by red and white LED lamps in a closed flat plate laboratory bioreactor on the growth rate and composition. The increase in solar irradiance led to faster growth rates $\left(\mu_{\exp }\right)$ of $C$. vulgaris under both environmental conditions studied in the greenhouse (in June up to $0.33 \mathrm{~d}^{-1}$ and in September up to $0.29 \mathrm{~d}^{-1}$ ) and higher lipid content in microalgal biomass (in June up to $25.6 \%$ and in September up to $24.7 \%$ ). In the experiments conducted in the closed bioreactor, as the ratio $\mathrm{I}_{420-520} / \mathrm{I}_{580-680}$ increased, the specific growth rate and the biomass, protein and lipid productivities increased as well. Additionally, the increase in light intensity with red and white LED lamps resulted in faster growth rates (the $\mu_{\exp }$ increased up to $0.36 \mathrm{~d}^{-1}$ ) and higher lipid content (up to $22.2 \%$ ), while the protein, fiber, ash and moisture content remained relatively constant. Overall, the trend in biomass, lipid, and protein productivities as a function of light intensity was similar in the two systems (greenhouse and bioreactor).
\end{abstract}

Keywords: biomass productivity; closed laboratory bioreactor; greenhouse; microalgae

\section{Introduction}

Microalgae are unicellular photosynthetic organisms that use light and carbon dioxide for growth and biomass production [1]. There are also species that can grow and produce biomass heterotrophically by using an organic carbon source under dark conditions [2]. Microalgae can grow in a variety of habitats, such as rivers, lakes, pounds, oceans, wastewaters, and even deserts. Their biodiversity is large; there are species that prosper in fresh water, such as Chlorella vulgaris, and others in saltwater.

Microalgae have different applications in many sectors. As photosynthetic organisms, they contain chlorophylls that can be used for food and cosmetic purposes [3]. Specifically, high value products can be produced by microalgae, such as carotenoids, astaxanthin, antioxidants, and the long chain polyunsaturated fatty acids: docosahexaenoic acid (DHA), eicosapentaenoic acid (EPA), and arachidonic acid (AA) [4] that can be used as nutritional supplements for human nutrition and as feed ingredient in diets for animals and fish [5]. Another application of microalgae has been found in food industry, where they are utilized as food dyes in candies, chewing gums, or beverages [6]. Additionally, biodiesel can be produced from their lipids due to their advantages over terrestrial plants, 
including high growth rate, ability to grow in non-fertile land all year round, as well as in saline water or coastal seawater [7]. It should be mentioned that for biodiesel production, the microalgae species should fulfill some prerequisites, such as high lipid content, high biomass production, and production at a low cost [8].

The system and the type of bioreactor used for microalgae cultivation is one of the most important parameters in microalgal cultivation. The design should accord with the species cultivated and the purpose of culture. The cultivation of microalgae can be carried out either in open or closed systems. Open-field cultivation is usually conducted in open raceway bioreactors that are exposed to the environment. They can be designed in different shapes and sizes. Different materials can be used for construction, such as clay, cement, PVC sheets, glass, fiber, polyethylene, or brick [9]. In general, the swallow bioreactors are preferred so that microalgae are exposed to a sufficient amount of light.

Cultivation in closed systems can be carried out in photobioreactors of various configurations. They can be located either outdoors (illumination with natural light) or indoors (illumination with artificial light). In closed systems, the production of biomass is higher than it is in the open systems and the risk of contamination of the cultivation is lower.

Additionally, the growth conditions (such as concentration of nutrients in the culture medium, temperature, $\mathrm{pH}$, light intensity, and oxygen and $\mathrm{CO}_{2}$ concentration) can be easily monitored [10]. What is more, the evaporation and loss of $\mathrm{CO}_{2}$ is low in comparison with cultivation in open systems [11]. However, investment, operating costs and energy requirements, as well as the cost for sterilization are higher than in open systems [12].

The microalgae culture systems depend on specific species and are influenced by different factors, such as temperature, light intensity, carbon dioxide concentration, $\mathrm{pH}$, configuration of bioreactor, mixing, salinity, and nutrient composition of the culture medium [13]. Light intensity is one of the most important cultivation parameters in microalgal growth and biomass production [14]. Apart from the regulation of biological processes, both the composition of biomass and their production are dependent on light intensity [15]. Light intensity affects the photosynthesis of microalgae and consequently their growth rate. Microalgae require light to produce ATP and NADPH and synthesize essential molecules for growth [16]. In general, increasing light intensity increases the growth rate of microalgae up to a certain point, which depends on specific microalgae species. However, high levels of light intensity up to saturation point may lead to photo-inhibition [17]. On the other hand, if light intensity is below the saturation point, microalgae growth will be limited [18]. It is known that when the cultivation is practiced under stress conditions, such as very high or low light intensities [19], a decrease in growth rate and biomass production is observed [20].

Not only intensity of light, but also quality plays an important role in growth rate and biomass production of microalgae. In C. vulgaris at a continuous irradiance of 70 and $140 \mu \mathrm{E} \mathrm{m}^{-2} \mathrm{~s}^{-1}$ with fluorescent lamps $(60 \mathrm{~W})$ of cold white light, the maximum concentration of cells and biomass were observed when cultivated at $140 \mu \mathrm{E} \mathrm{m}^{-2} \mathrm{~s}^{-1}$ under white light and blue light in comparison with violet and yellow light sources [21]. Consequently, the increase of light intensity from $70 \mu \mathrm{E} \mathrm{m} \mathrm{m}^{-2} \mathrm{~s}^{-1}$ to $140 \mu \mathrm{E} \mathrm{m}^{-2} \mathrm{~s}^{-1}$ resulted in an increase in growth rate in the specific species. In the same species, Khalili et al. [22] studied the effect of different light intensities (50, 80, and $110 \mu \mathrm{mol} \mathrm{m}^{-2} \mathrm{~s}^{-1}$ ) and different wavelengths (red, blue, natural white, and warm white) on growth rate of $C$. vulgaris. The highest growth was observed at light intensity of $80 \mu \mathrm{mol} \mathrm{m} \mathrm{m}^{-2} \mathrm{~s}^{-1}$. A light intensity of $50 \mu \mathrm{mol} \mathrm{m} \mathrm{m}^{-2} \mathrm{~s}^{-1}$ was not adequate for microalgae growth, while $110 \mu \mathrm{mol} \mathrm{m}^{-2} \mathrm{~s}^{-1}$ of light intensity was too high causing photo-inhibition. The growth of $C$. vulgaris was higher under warm white light in comparison with red and blue light.

The composition of the biomass produced, that is lipids, proteins and carbohydrates, is affected by the environmental and cultural conditions, such as light intensity, temperature, $\mathrm{pH}$, and nutrient availability in the culture medium [23-25]. In some microalgae species, such as Ankistrodesmus falcatus, low light intensities resulted in high lipid content, as reported by George et al. [26], while in other 
species—such as Chlorella sp., Monoraphidium sp. [27], and Botryococcus braunii [28]—the increase of light intensity resulted in higher lipid content.

In C. vulgaris, an increase in protein content was observed with increasing light intensity according to Baiee and Salman [29], while in Chlorella sp., under high light intensity, protein content decreased, according to He et al. [27]. The results of these two studies as far as the dependence of protein content of the biomass on light intensity are different but, the two studies differ in a number of experimental approaches of which most important are the following: the two species of Chlorella used are different. He et al. used Chlorella sp. L1 while, Baiee and Salman used a strain of Chlorella vulgaris that was isolated from artificial canal around University of Babylon campus near Al-Hilla city. Additionally, $\mathrm{He}$ et al., used continuous illumination, without a dark period, of 40,200 , and $400 \mu \mathrm{mol}$ photons $\mathrm{m}^{-2} \mathrm{~s}^{-1}$ using a daylight fluorescent lamp, while Baiee and Salman used three light intensities $(125,268$, and $300 \mu \mathrm{mol}$ photons $\mathrm{m}^{-2} \mathrm{~s}^{-1}$ ) for cultivation and no mention either of the light/dark period or the type of lamp used is made.

The innovation of the present study lies in cultivation of microalgae not only under controlled conditions of laboratory bioreactors, but also under natural conditions in a greenhouse environment, where temperature and light intensity were allowed to fluctuate naturally. This should be of value in a potential commercial cultivation in open pond or raceway systems. In the experiments conducted in the closed laboratory bioreactor, the innovation lies in cultivation by taking into consideration the ratio of light in the 420-520 nm range to light in the 580-680 nm range and not under monochromatic light independently (such as blue, red, green) or white. Additionally, cultivation was practiced in a small pilot scale ( 3 bioreactors of $50 \mathrm{~L}$ capacity each that is $150 \mathrm{~L}$ per treatment in each experiment), while most of studies are done in flasks of 1-5 L capacity.

Therefore, the present study was conducted in order to examine how the growth rate (determined by the specific growth rate and the biomass productivity) as well as the composition of Chlorella vulgaris were effected by: (a) the intensity of solar irradiation in the greenhouse during June and September; (b) the ratio of intensities of light in the $420-520 \mathrm{~nm}$ range to light in the 580-680 $\mathrm{nm}$ range $\left(\mathrm{I}_{420-520} / \mathrm{I}_{580-680}\right)$; and (c) the intensity of artificial irradiation with white and red LED lamps in a closed flat plate laboratory bioreactor.

\section{Materials and Methods}

\subsection{Microalga Cultivation}

The microalga species (SAG Strain Number: C. vulgaris: 211-11b) was obtained from the Experimental Phycology and Culture Collection of Algae from the University of Goettingen in Germany (EPSAG). It was cultivated in two different sets of experiments: the 1st set was conducted in a greenhouse in order to study the effect of solar irradiation at two different environmental conditions (during June and September). The second set of experiments was conducted in a closed laboratory bioreactor in order to study: a) the ratio $\left(\mathrm{I}_{420-520} / \mathrm{I}_{580-680}\right)$ of light in the $420-520 \mathrm{~nm}$ range to light in the 580-680 nm range; and b) the intensity of artificial irradiation with white and red LED lamps at a constant ratio $\left(\mathrm{I}_{420-520} / \mathrm{I}_{580-680}=0.90\right)$.

\subsubsection{Cultivation of $C$. vulgaris in the Greenhouse Environment}

In this set of experiments $C$. vulgaris was cultivated in open bioreactors of $50 \mathrm{~L}$ capacity each in a greenhouse (at two different environmental conditions during June and September) where temperatures and irradiation were allowed to fluctuate naturally. In June both sunlight intensity and sunlight duration are at a maximum. In September sunlight intensity and duration as well as temperatures are lower compared to June. In winter the very low temperatures and light intensities are not favorable to study the growth rate of $C$. vulgaris. Therefore, these two months were chosen in order to compare growth rates and nutrient composition of $C$. vulgaris. 
In June, the daily range of temperature fluctuation was between 30 and $36{ }^{\circ} \mathrm{C}$ which corresponds to an average temperature of $33^{\circ} \mathrm{C}$, while the average solar irradiation was equal to $I_{\text {average }}=16.1 \mathrm{MJ}$ $\mathrm{m}^{-2}$ day $^{-1}$ that equals to $186.3 \mathrm{~W} \mathrm{~m}^{-2}$ or $851.4 \mu \mathrm{mol}$ photons $\mathrm{m}^{-2} \mathrm{~s}^{-1}$. In September, the daily range of temperature fluctuation was between 28 and $32{ }^{\circ} \mathrm{C}$ which corresponds to an average temperature of $30^{\circ} \mathrm{C}$ and the average solar irradiation was equal to $I_{\text {average }}=11.4 \mathrm{MJ} \mathrm{m}^{-2}$ day $^{-1}$ that equals to $131.9 \mathrm{~W} \mathrm{~m}^{-2}$ or $598.7 \mu \mathrm{mol}$ photons $\mathrm{m}^{-2} \mathrm{~s}^{-1}$. During June the mean light: dark periods (in hours) were 14.75:9.25 while the corresponding ones in September were 12.25:11.75. The ratio of transmitted intensities between $420-520 \mathrm{~nm}$ and $580-680 \mathrm{~nm}$ of sunlight inside the greenhouse is about 0.98 . This was determined from the transmission spectrum of the greenhouse glass material.

Greenhouse nets were used to cover the bioreactors to reduce solar irradiance at $50 \%$ and $25 \%$, while the control (100\% solar irradiance) was not covered. The greenhouse was set aside for these cultivation experiments only. No other experiments were conducted at the same place to minimize disturbance and avoid any possibility of contamination. The greenhouse was covered with glass and was located at University of Thessaly in Larissa, Central Greece. The air temperature and solar radiation inside the greenhouse were measured and recorded using a meteorological station (Pessl Instruments, Austria) and the daily average values were calculated. Attention was paid so that all the bioreactors were exposed to similar light conditions. Three replications per treatment were performed.

\subsubsection{Cultivation of $C$. vulgaris in a Closed Laboratory Bioreactor}

The second set of experiments was conducted in a closed flat plate laboratory bioreactor of 25 L capacity (Photon Systems Instruments, Drasov, Czech Republic) in order to study the effect of the: (a) ratio of intensities of light in the $420-520 \mathrm{~nm}$ range to light in the $580-680 \mathrm{~nm}$ range $\left(\mathrm{I}_{420-520} / \mathrm{I}_{580-680}\right)$; and (b) intensity of artificial irradiation with white and red LED lamps at 520, 390, 260, and $130 \mu \mathrm{mol}$ photons $\mathrm{m}^{-2} \mathrm{~s}^{-1}$, keeping the ratio $\left(\mathrm{I}_{420-520} / \mathrm{I}_{580-680}\right)$ constant and equal to 0.90 . The temperature was fixed at $30^{\circ} \mathrm{C}$ to within $\pm 0.1^{\circ} \mathrm{C}$. The cultivations were illuminated with red and white LED lamps on 12:12 h light-dark cycles.

(a) In the experiments of variable ratio of intensities in the wavelength range of 420-520 nm and of $580-680 \mathrm{~nm}$, four different ratios of light in the range of 420-520 nm to light in the range of 580-680 nm were studied $\left(\mathrm{I}_{420-520} / \mathrm{I}_{580-680}\right)$, namely: $0.30,0.60,0.90$, and 1.30 . This was achieved by integrating the intensity in each of the above ranges and then combining the intensities from both lamps in such a way that the total intensity of illumination (LED lamps) was kept constant at about $420 \mu$ mol photons $\mathrm{m}^{-2}$ $\mathrm{s}^{-1}$.

(b) In the variable intensity experiments, the ratio $\left(\mathrm{I}_{420-520} / \mathrm{I}_{580-680}\right)$ was kept constant at 0.90 while the total intensity of artificial illumination provided by red and white LED lamps varied. Total intensities of 520, 390, 260, and $130 \mu \mathrm{mol}$ photons $\mathrm{m}^{-2} \mathrm{~s}^{-1}$ were studied. Three replications per treatment were performed.

It is known that chlorophyll $\mathrm{a}$ and $\mathrm{b}$ are the main constituents of the chloroplasts of green microalgae. The wavelength ranges where the two chlorophylls absorb were determined from their absorption spectrum. These ranges are from below $400 \mathrm{~nm}$ up to $520 \mathrm{~nm}$ and from $580 \mathrm{~nm}$ to about $680 \mathrm{~nm}$. Chlorophylls hardly absorb between $520 \mathrm{~nm}$ and $580 \mathrm{~nm}$. The white LED lamp of the bioreactor emits in the range between $420-680 \mathrm{~nm}$ (range where both chlorophylls absorb). The red LED lamp of the bioreactor emits only in the range of 600-665 nm. For these reasons, the ratio of intensities of light in the $420-520 \mathrm{~nm}$ range to $580-680 \mathrm{~nm}$ range intensities was chosen for study.

It should be mentioned that the intensities of the two lamps of the bioreactor, which have different emission spectra, can be varied independently. White LED lamp intensity can be varied from 0 up to $707 \mu \mathrm{mol}$ photons $\mathrm{m}^{-2} \mathrm{~s}^{-1}$, while the red LED lamp intensity can be varied from 0 up to $240 \mu \mathrm{mol}$ photons $\mathrm{m}^{-2} \mathrm{~s}^{-1}$. The power of each lamp can be varied independently by a setting in the PC of the bioreactor. The power output has been initially calibrated by the manufacturer of the bioreactor and occasionally it is recalibrated in the laboratory through a procedure described by the manual of the instrument. 
According to our calculations, the ratio of the ranges $420-520 \mathrm{~nm}$ and $580-680 \mathrm{~nm}$ in natural sunlight is around 0.90. For this reason, this ratio was used as a reference in the second set of experiments and kept constant in order to examine the effect of intensity of artificial irradiation with white and red LED lamps on the growth rate and nutrient composition of the biomass of $C$. vulgaris. It is noted that the ranges $420-520 \mathrm{~nm}$ and $580-680 \mathrm{~nm}$ correspond best to the blue and red ranges of the bioreactor lamps used in these experiments. Therefore, this is the best simulation of natural sunlight absorbed by the chlorophylls.

\subsubsection{Culture Medium}

In each set of experiments, C. vulgaris was grown in Basal Medium (= ES - ("Erddekokt + Salze") containing the following nutrients per L: $20 \mathrm{~mL}$ from a stock solution containing $1 \mathrm{~g} / 100 \mathrm{~mL}$ $\mathrm{KNO}_{3}, 20 \mathrm{~mL}$ from a stock solution containing $0.1 \mathrm{~g} / 100 \mathrm{~mL} \mathrm{~K}_{2} \mathrm{HPO}_{4}, 20 \mathrm{~mL}$ from a stock solution containing $0.1 \mathrm{~g} / 100 \mathrm{~mL} \mathrm{MgSO} \cdot 7 \mathrm{H}_{2} \mathrm{O}$ and $30 \mathrm{~mL}$ of soil extract that was prepared as follows: in a $6 \mathrm{~L}$ flask, one-third was filled with garden or leaf soil of medium, but not too great humus content which did not contain fertilizers or plant protective agents. De-ionized water was added until it stood $5 \mathrm{~cm}$ above the soil and sterilized by heating in a steamer for one hour twice in a $24 \mathrm{~h}$ interval. The decanted extract was separated from particles by centrifugation and was filled into small containers of stock solution each of a size appropriate to making a batch of media, autoclaved for $20 \mathrm{~min}$ at $121{ }^{\circ} \mathrm{C}$ and stored in the refrigerator. Additionally, it contained $5 \mathrm{~mL}$ per L from a micronutrient solution containing: $0.005 \mathrm{mg} \mathrm{L}^{-1} \mathrm{ZnSO}_{4} \cdot 7 \mathrm{H}_{2} \mathrm{O}, 0.01 \mathrm{mg} \mathrm{L}^{-1} \mathrm{MnSO}_{4} \cdot 4 \mathrm{H}_{2} \mathrm{O}, 0.05 \mathrm{mg} \mathrm{L}^{-1}$ $\mathrm{H}_{3} \mathrm{BO}_{3}, 0.005 \mathrm{mg} \mathrm{L}^{-1} \mathrm{Co}\left(\mathrm{NO}_{3}\right)_{2} \cdot 6 \mathrm{H}_{2} \mathrm{O}, 0.005 \mathrm{mg} \mathrm{L}^{-1} \mathrm{Na}_{2} \mathrm{MoO}_{4} \cdot 2 \mathrm{H}_{2} \mathrm{O}, 0.000025 \mathrm{mg} \mathrm{L}^{-1} \mathrm{CuSO}_{4} \cdot 5 \mathrm{H}_{2} \mathrm{O}$, $3.5 \mathrm{mg} \mathrm{L}^{-1} \mathrm{FeSO}_{4} \cdot 7 \mathrm{H}_{2} \mathrm{O}, 4 \mathrm{mg} \mathrm{L}^{-1}$ EDTA, and $905 \mathrm{~mL} \mathrm{~L}^{-1}$ de-ionized water [30].

The cultivation of the inoculum was done always under the same conditions namely, at a temperature of $25^{\circ} \mathrm{C}$, under natural illumination and by using an orbital shaker at $60 \mathrm{rpm}$ in order to prevent sticking of microalgae to the surfaces of the flask until they reached an absorbance reading of 0.5 . The initial volume of culture was always the same that is $250 \mathrm{~mL}$ for the experiments conducted in the open bioreactors of $50 \mathrm{~L}$ capacity in the greenhouse and $125 \mathrm{~mL}$ for the experiments conducted in the closed laboratory bioreactor of $25 \mathrm{~L}$ capacity.

\subsection{Measurements}

The microalgae concentration was determined daily by optical density measurements at $655 \mathrm{~nm}$ with the use of a UV-Vis spectrophotometer (Cintra 101 Model- GBC, Melbourne, Australia). The highest peak after scanning the visible wavelength range with cultivated samples of $C$. vulgaris was found at about $655 \mathrm{~nm}$ and for this reason it was chosen to measure the absorbance of the cultures. Three samples were collected daily from each culture and all measurements were carried out in triplicate. Additionally, samples taken from all cultures for the determination of absorbance were randomly subjected at all stages of cultivation (exponential and stationary growth phase) to examination in the microscope. No contamination by bacteria was found. Also, both macroscopically and under the microscope, the pigmentation of microalgae was vividly green.

At the end of each experiment, the total productivity of each culture was measured (in $\mathrm{g} \mathrm{L}^{-1} \mathrm{~d}^{-1}$ ) as dry weight $(\mathrm{dw})$, after harvest of the biomass by a process which was aided by raising the $\mathrm{pH}$ of the culture medium, in order to cause the microalgae to flocculate $[31,32]$. The $\mathrm{pH}$ was raised by adding sodium hydroxide, which induces more than $90 \%$ flocculation at $\mathrm{pH} 11$ [33]. After sedimentation, the supernatant medium was removed, the condensates were collected and the excess water was evaporated in an air circulation oven at $40{ }^{\circ} \mathrm{C}$. The biomass was stored at $-20{ }^{\circ} \mathrm{C}$ and prior to biochemical analysis it was pulverized using a planetary ball mill at $180 \mathrm{rpm}$ for 10 minutes (FRITSCH, Idar-Oberstein, Germany). 
The specific growth rate in the exponential growth phase ( $\mu_{\text {exp }}$, slope of the growth rate curve in the exponential phase) was calculated according to the relation

$$
\mu_{\exp }=\ln \left(\alpha_{2} / \alpha_{1}\right) /\left(t_{2}-t_{1}\right)
$$

where $\alpha_{1}$ and $\alpha_{2}$ are the absorbance readings at the beginning and the end of exponential growth phase, at time $1\left(t_{1}\right)$ and $2\left(t_{2}\right)$, respectively.

Lipid and protein productivities $\left(\mathrm{P}_{1}, \mathrm{P}_{\mathrm{p}}\right.$, in $\left.\mathrm{g} \mathrm{L}^{-1} \mathrm{~d}^{-1}\right)$ were calculated from the biomass productivities $\left(\mathrm{P}_{\mathrm{b}}\right)$ and lipid and protein content of biomass as dry weight $(\mathrm{dw})$ respectively

$$
\begin{gathered}
\mathrm{P}_{1}=\mathrm{P}_{\mathrm{b}} \times \mathrm{C}_{1} \\
\mathrm{P}_{\mathrm{p}}=\mathrm{P}_{\mathrm{b}} \times \mathrm{C}_{\mathrm{p}}
\end{gathered}
$$

where, $\mathrm{P}_{\mathrm{b}}$ is the biomass productivity in $\mathrm{g} \mathrm{L}^{-1} \mathrm{~d}^{-1}$ and $\mathrm{C}_{1}$ and $\mathrm{C}_{\mathrm{p}}$ are the lipid and protein fraction content of the biomass of $C$. vulgaris respectively.

\subsection{Nutrient Composition Analyses}

The nutrient composition of the samples was determined according to AOAC (1995) [34] methods. Specifically, the determination of protein content of samples was performed with Kjeldahl method. In Kjeldahl flasks, catalyst (potassium sulphate and copper sulphate) was added in the samples with sulphuric acid $\left(\mathrm{H}_{2} \mathrm{SO}_{4}\right)$ and boiled for $85 \mathrm{~min}$. After cooling, samples were distilled with $\mathrm{NaOH}$, distilled water and $\mathrm{H}_{3} \mathrm{BO}_{3}$. After the distillation was finished, the $\mathrm{H}_{3} \mathrm{BO}_{3}$ was titrated with $\mathrm{HCl}$ $(0.1 \mathrm{~N})$ by adding an indicator (methyl red) and total protein content of samples was calculated using a conversion factor of 6.25 [35].

Moisture content was determined by drying the samples in an oven at $105^{\circ} \mathrm{C}$ until constant weight. To measure total lipid content, lipids were extracted from the samples with the method of Folch et al. [36] with 1:1 chloroform/methanol, because according to Ryckebosch et al. [37], chloroform-methanol 1:1 was shown to be the best solvent mixture for extraction of total lipids from microalgae instead of 2:1. Samples were placed in glass, stoppered tubes together with $\mathrm{C}: \mathrm{M}(1: 1, v / v)$ and were allowed to stand on ice for approximately 3 hours to ensure that extraction of all lipids occurred. $\mathrm{KCl} 0.88 \%$ $(w / v)$ in distilled water was added to the samples. The mixture was shaken vigorously. The organic layer that contains the purified lipid was separated from the aqueous layer that contains the non-lipid contaminants by centrifugation. The upper aqueous layer was carefully discarded by aspiration and the lower organic phase was filtered through a filter paper into a new pre-weighed test tube. The solvent was evaporated under a stream of oxygen-free nitrogen. The dried total lipid extract was determined gravimetrically.

Ash content of the samples was determined with incineration at $600{ }^{\circ} \mathrm{C}$. To determine the content of samples in crude fiber, the samples were boiled: (a) in $0.128 \mathrm{M} \mathrm{H}_{2} \mathrm{SO}_{4}$ solution for $30 \mathrm{~min}$, washing the remaining solids twice in hot water and drying it in an oven at $105^{\circ} \mathrm{C}$; and $(\mathrm{b})$ in $0.128 \mathrm{M} \mathrm{KOH}$ solution following the same procedure. The weight of the remaining solids was determined. The remaining solids were incinerated at $600{ }^{\circ} \mathrm{C}$ until constant weight obtained and ashes were weighed in order to determine the ash content of samples. The difference in initial and final weight is the content of biomass in crude fiber.

Nitrogen-free extractable (NFE) represents the non-structural carbohydrates, primarily of readily available carbohydrates and any solubilized hemicellulose and lignin. They were calculated by difference from the equation

$$
\% \text { NFE }=100-(\% \mathrm{CP}+\% \mathrm{TL}+\% \mathrm{Ash}+\% \mathrm{CF}+\% \text { Moisture })
$$

where: $\mathrm{CP}=$ crude protein, $\mathrm{TL}=$ total lipids, and $\mathrm{CF}=$ crude fiber 


\subsection{Algal Growth Kinetic Model as a Function of Light Intensity}

In this study, the following Monod saturation function was used to correlate the light intensity with the specific growth rate in the exponential phase $(\mu)$ of $C$. vulgaris cultivated in the bioreactor at different light intensities provided by white and red LED lamps

$$
\mu=\mu \max \frac{I}{K+I}
$$

where $\mu$ is the specific growth rate of $C$. vulgaris, $\mu_{\max }$ is the maximum specific growth rate of $C$. vulgaris, $I$ is the light intensity, and $\mathrm{K}$ is a constant.

\subsection{Statistical Analysis}

Statistical analysis was performed using the one-way analysis of variance (ANOVA) and Tukey's multiple comparison test, to determine differences between treatments at significance level of 0.05 . All statistics were carried out using the IBM SPSS Statistics 24 statistical package (Armonk, NY, USA).

\section{Results}

\subsection{Growth Rate of C. vulgaris in the Greenhouse}

Figure $1 \mathrm{a}, \mathrm{b}$ illustrates the absorbance readings versus the cultivation time of $C$. vulgaris during June (1-a) and September (1-b) in the greenhouse at $100 \%, 50 \%$, and $25 \%$ of solar irradiance. It was found that the growth rate of $C$. vulgaris was strongly dependent on the light intensity in both experimental periods (June and September). The maximum absorbance readings were $0.70,0.54$, and 0.36 for cultivation in June at $100 \%, 50 \%$, and $25 \%$ of solar irradiance respectively and $0.60,0.45$, and 0.30 for September. The increase in solar irradiance from $25 \%$ to $50 \%$ and to $100 \%$ both in June and September, led to consequent increases in specific growth rates in the exponential growth phase $\left(\mu_{\exp }\right)$, in maximum absorbance readings and in total biomass productivities $\left(\mathrm{P}_{\mathrm{b}}\right)$ (Table 1$)$.

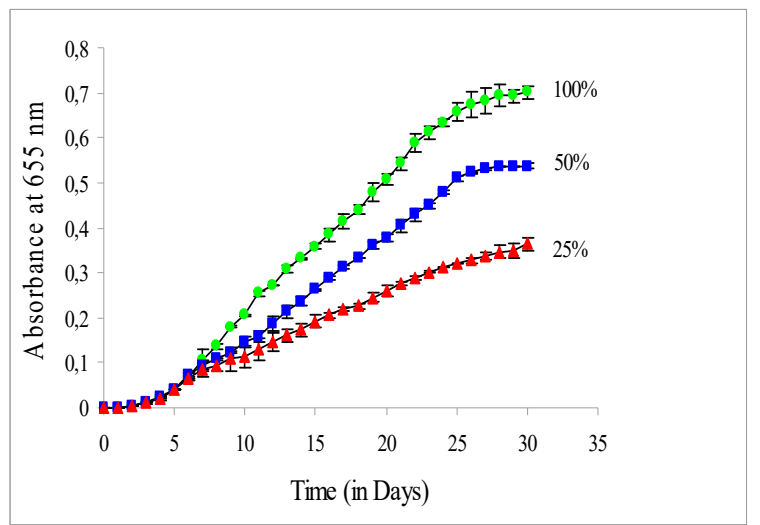

(a)



(b)

Figure 1. Growth curves of C. vulgaris cultivated during June (a) and September (b) in the greenhouse at $100 \%, 50 \%$, and $25 \%$ of solar irradiance. The error bars represent the standard deviation of the means. 
Table 1. Specific growth rates $\left(\mu_{\text {exp }}\right)$ in the exponential growth phase (in $\left.\mathrm{d}^{-1}\right)$ and biomass $\left(\mathrm{P}_{\mathrm{b}}\right)$, lipid $\left(\mathrm{P}_{1}\right)$, and protein $\left(\mathrm{P}_{\mathrm{p}}\right)$ productivities (in $\left.\mathrm{g} \mathrm{L}^{-1} \mathrm{~d}^{-1}\right)$ of $C$. vulgaris cultivated during June and September in the greenhouse at $100 \%, 50 \%$ and $25 \%$ of solar irradiance.

\begin{tabular}{cccc}
\hline \multirow{2}{*}{$\begin{array}{c}\text { Growth Rate (in d } \\
\text { Productivity (in } \mathbf{g ~ L}^{-\mathbf{1}} \mathbf{d}^{\mathbf{- 1}} \text { ) }\end{array}$} & \multicolumn{3}{c}{ Solar Irradiance } \\
\cline { 2 - 4 } & $\mathbf{1 0 0 \%}$ & $\mathbf{5 0 \%}$ & $\mathbf{2 5 \%}$ \\
\hline$\mu_{\exp }$ & $0.329 \pm 0.030^{\mathrm{a}}$ & $0.252 \pm 0.022^{\mathrm{b}}$ & $0.181 \pm 0.020^{\mathrm{c}}$ \\
$\mathrm{P}_{\mathrm{b}}$ & $0.022 \pm 0.001^{\mathrm{a}}$ & $0.015 \pm 0.002^{\mathrm{b}}$ & $0.011 \pm 0.000^{\mathrm{c}}$ \\
$\mathrm{P}_{1}$ & $0.006 \pm 0.000^{\mathrm{a}}$ & $0.003 \pm 0.000^{\mathrm{b}}$ & $0.002 \pm 0.000^{\mathrm{c}}$ \\
$\mathrm{P}_{\mathrm{p}}$ & $0.005 \pm 0.000^{\mathrm{a}}$ & $0.004 \pm 0.000^{\mathrm{b}}$ & $0.003 \pm 0.000^{\mathrm{c}}$ \\
\hline & September & & \\
\hline$\mu_{\exp }$ & $0.293 \pm 0.033^{\mathrm{a}}$ & $0.221 \pm 0.022^{\mathrm{b}}$ & $0.169 \pm 0.020^{\mathrm{c}}$ \\
$\mathrm{P}_{\mathrm{b}}$ & $0.018 \pm 0.001^{\mathrm{a}}$ & $0.014 \pm 0.001^{\mathrm{b}}$ & $0.010 \pm 0.001^{\mathrm{c}}$ \\
$\mathrm{P}_{1}$ & $0.004 \pm 0.000^{\mathrm{a}}$ & $0.003 \pm 0.000^{\mathrm{b}}$ & $0.002 \pm 0.000^{\mathrm{c}}$ \\
$\mathrm{P}_{\mathrm{p}}$ & $0.005 \pm 0.000^{\mathrm{a}}$ & $0.004 \pm 0.000^{\mathrm{b}}$ & $0.003 \pm 0.000^{\mathrm{c}}$ \\
\hline
\end{tabular}

Values represent averages \pm std. deviation $(n=3)$. Values in the same row followed by different superscript indicate statistically significant difference $(p<0.05)$.

\subsection{Composition of C. vulgaris in the Greenhouse}

Light intensity (solar irradiance) did not significantly affect the protein, fiber, moisture, and ash content of the biomass of $C$. vulgaris (Table 2). On the other hand, the NFE content decreased with the increase of light intensity, while the lipid content of the biomass of $C$. vulgaris increased significantly with the increase of light intensity from $25 \%$ to $100 \%$. In June, the lipid content increased from $19.5 \%$ to $25.6 \%$ and in September from $17.3 \%$ to $24.7 \%$ (Table 2). Lipid and protein productivities were highest at $100 \%$ solar irradiance and lowest at $25 \%$ solar irradiance as a result of higher biomass productivity (Table 1).

Table 2. Composition (\%) of C. vulgaris cultivated during June and September in the greenhouse at $100 \%, 50 \%$, and $25 \%$ of solar irradiance.

\begin{tabular}{|c|c|c|c|c|c|c|}
\hline $\begin{array}{c}\text { Solar } \\
\text { Irradiance }\end{array}$ & Moisture & Lipids & Proteins & Ash & Fiber & NFE \\
\hline \multicolumn{7}{|c|}{ June } \\
\hline $50 \%$ & $7.950 \pm 0.311^{a}$ & $22.279 \pm 0.157^{b}$ & $23.606 \pm 0.817^{\mathrm{a}}$ & $12.375 \pm 0.299^{a}$ & $9.325 \pm 0.189^{a}$ & $24.466 \pm 0.990^{b}$ \\
\hline $25 \%$ & $8.050 \pm 0.191^{a}$ & $19.456 \pm 0.342^{c}$ & $23.801 \pm 0.651^{\mathrm{a}}$ & $12.275 \pm 0.359^{a}$ & $9.225 \pm 0.320^{a}$ & $27.193 \pm 0.730^{a}$ \\
\hline \multicolumn{7}{|c|}{ September } \\
\hline $50 \%$ & $7.975 \pm 0.171^{a}$ & $21.300 \pm 0.269^{b}$ & $27.563 \pm 0.878^{a}$ & $12.338 \pm 0.229^{a}$ & $9.300 \pm 0.365^{\mathrm{a}}$ & $21.524 \pm 1.200^{b}$ \\
\hline $25 \%$ & $8.000 \pm 0.082^{a}$ & $17.292 \pm 0.267^{c}$ & $27.121 \pm 0.794^{\mathrm{a}}$ & $12.275 \pm 0.386^{\mathrm{a}}$ & $9.475 \pm 0.206^{\mathrm{a}}$ & $25.837 \pm 0.681^{a}$ \\
\hline
\end{tabular}

Values represent averages \pm std. deviation $(n=9)$. Values in the same column followed by different superscript indicate statistically significant difference $(p<0.05)$.

\subsection{Growth rate of $C$. vulgaris in the Closed Bioreactor}

Figure 2a,b illustrates the absorbance readings versus the cultivation time of $C$. vulgaris: (Figure 2a) at four different ratios $\left(\mathrm{I}_{420-520} / \mathrm{I}_{580-680}\right)$ of light in the range of $420-520 \mathrm{~nm}$ to light in the range of 580-680 $\mathrm{nm}$ and (Figure 2b) at four different artificial irradiations with white and red LED lamps in the bioreactor at a constant ratio $\left(\mathrm{I}_{420-520} / \mathrm{I}_{580-680}\right.$ equal to 0.90$)$. The growth rate of $C$. vulgaris was strongly dependent on the ratio $\mathrm{I}_{420-520} / \mathrm{I}_{580-680}$. As the ratio $\mathrm{I}_{420-520} / \mathrm{I}_{580-680}$ increased, the maximum absorbance (Figure $2 \mathrm{a})$, the specific growth rate $\left(\mu_{\exp }\right)$ in exponential phase and the total biomass productivity increased as well (Table 3 ). 


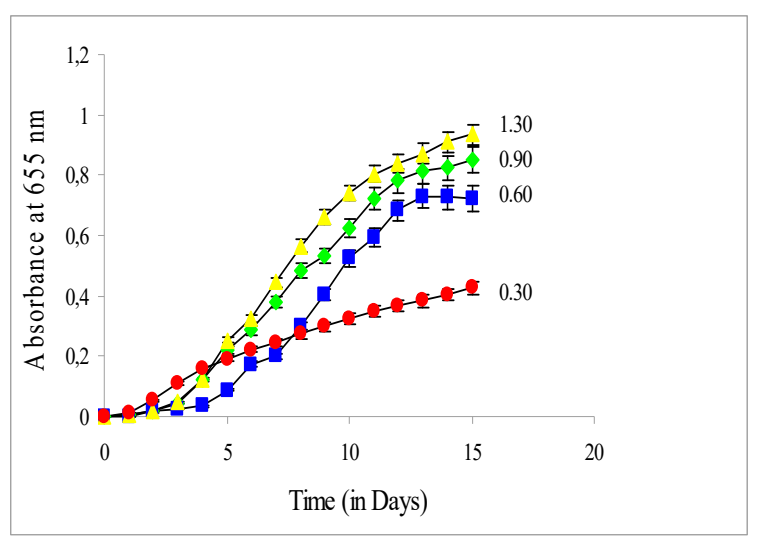

(a)

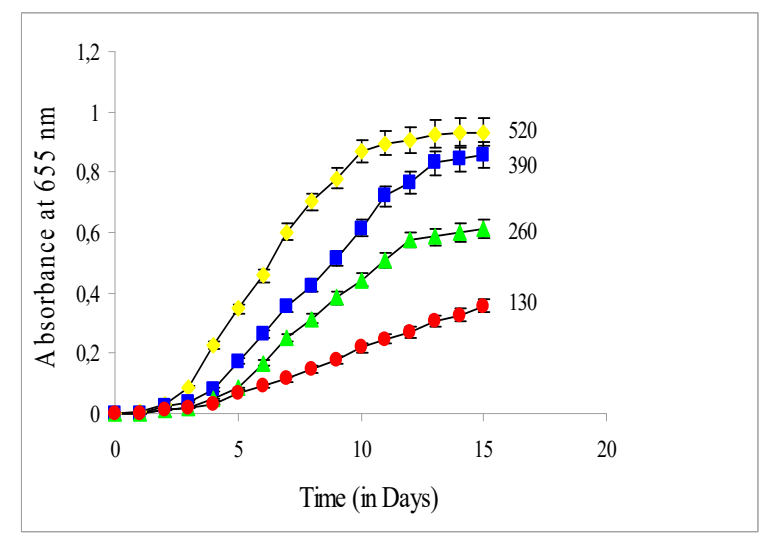

(b)

Figure 2. (a,b) Growth curves of $C$. vulgaris cultivated at four different ratios $\left(\mathrm{I}_{420-520} / \mathrm{I}_{580-680}\right)(\mathbf{a})$ and at four different artificial irradiations with white and red LED lamps in the bioreactor (in $\mu \mathrm{mol}$ photons $\left.\mathrm{m}^{-2} \mathrm{~s}^{-1}\right)(\mathbf{b})$. The error bars represent the standard deviation of the means.

Table 3. Specific growth rates $\left(\mu_{\exp }\right)$ in exponential growth phase (in $\mathrm{d}^{-1}$ ) and biomass $\left(\mathrm{P}_{\mathrm{b}}\right)$, lipid $\left(\mathrm{P}_{1}\right)$, and protein $\left(\mathrm{P}_{\mathrm{p}}\right)$ productivities (in $\left.\mathrm{g} \mathrm{L}^{-1} \mathrm{~d}^{-1}\right)$ of $C$. vulgaris cultivated at four different ratios $\left(\mathrm{I}_{420-520} / \mathrm{I}_{580-680}\right)$ and at four different light intensities with white and red LED lamps in the bioreactor.

\begin{tabular}{|c|c|c|c|c|}
\hline \multirow{2}{*}{$\begin{array}{l}\text { Growth Rate (in } \mathrm{d}^{-1} \text { ) and } \\
\text { Productivity (in } \mathrm{g} \mathrm{L}^{-1} \mathrm{~d}^{-1} \text { ) }\end{array}$} & \multicolumn{4}{|c|}{$\mathrm{I}_{420-520} / \mathrm{I}_{580-680}$} \\
\hline & 1.30 & 0.90 & 0.60 & 0.30 \\
\hline$\mu_{\exp }$ & $0.394 \pm 0.021^{\mathrm{a}}$ & $0.346 \pm 0.022^{b}$ & $0.266 \pm 0.031^{c}$ & $0.183 \pm 0.023^{d}$ \\
\hline $\mathrm{P}_{\mathrm{b}}$ & $0.080 \pm 0.004^{\mathrm{a}}$ & $0.060 \pm 0.001^{b}$ & $0.041 \pm 0.002^{c}$ & $0.030 \pm 0.002^{d}$ \\
\hline $\mathrm{P}_{1}$ & $0.010 \pm 0.000^{\mathrm{a}}$ & $0.009 \pm 0.000^{\mathrm{a}}$ & $0.008 \pm 0.000^{b}$ & $0.006 \pm 0.000^{c}$ \\
\hline \multirow[t]{3}{*}{$\mathrm{P}_{\mathrm{p}}$} & $0.021 \pm 0.000^{\mathrm{a}}$ & $0.015 \pm 0.000^{b}$ & $0.010 \pm 0.000^{c}$ & $0.008 \pm 0.000^{\mathrm{d}}$ \\
\hline & \multicolumn{4}{|c|}{ Light Intensity ( $\mu \mathrm{mol}$ Photons $\mathrm{m}^{-2} \mathrm{~s}^{-1}$ ) } \\
\hline & 520 & 390 & 260 & 130 \\
\hline$\mu_{\exp }$ & $0.363 \pm 0.023^{a}$ & $0.318 \pm 0.020^{b}$ & $0.276 \pm 0.011^{c}$ & $0.166 \pm 0.020^{\mathrm{d}}$ \\
\hline $\mathrm{P}_{\mathrm{b}}$ & $0.085 \pm 0.001^{\mathrm{a}}$ & $0.054 \pm 0.001^{b}$ & $0.041 \pm 0.001^{c}$ & $0.032 \pm 0.003^{\mathrm{d}}$ \\
\hline $\mathrm{P}_{1}$ & $0.019 \pm 0.000^{\mathrm{a}}$ & $0.008 \pm 0.000^{b}$ & $0.004 \pm 0.000^{\mathrm{c}}$ & $0.003 \pm 0.000^{d}$ \\
\hline $\mathrm{P}_{\mathrm{p}}$ & $0.022 \pm 0.000^{\mathrm{a}}$ & $0.014 \pm 0.000^{b}$ & $0.010 \pm 0.000^{\mathrm{c}}$ & $0.008 \pm 0.000^{\mathrm{d}}$ \\
\hline
\end{tabular}

Values represent averages \pm std. deviation $(n=3)$. Values in the same row followed by different superscript indicate statistically significant difference $(p<0.05)$.

Concerning the experiments where the intensity of artificial irradiation with white and red LED lamps at 520, 390, 260, and $130 \mu \mathrm{mol}$ photons $\mathrm{m}^{-2} \mathrm{~s}^{-1}$ was studied, it was found that the increase from $130 \mu \mathrm{mol} \mathrm{m} \mathrm{m}^{-2} \mathrm{~s}^{-1}$ to 260 , to 390 and to $520 \mu \mathrm{mol}$ photons $\mathrm{m}^{-2} \mathrm{~s}^{-1}$, led to consequent increases in specific growth rates in the exponential growth phase $\left(\mu_{\text {exp }}\right)$, in maximum absorbance readings and in total biomass productivities (Table 3). Lipid and protein productivities were highest in light intensity equal to $520 \mu \mathrm{mol}$ photons $\mathrm{m}^{-2} \mathrm{~s}^{-1}$, due to higher biomass productivity.

\subsection{Composition of C. vulgaris in the Closed Bioreactor}

The compositions of biomass of $C$. vulgaris cultivated at four different ratios $\left(\mathrm{I}_{420-520} / \mathrm{I}_{580-680}\right)$ and at four different artificial irradiations at a constant ratio $\left(\mathrm{I}_{420-520} / \mathrm{I}_{580-680}\right.$ equal to 0.90$)$ with white and red LED lamps in the bioreactor are presented in Table 4. The ratio $\left(\mathrm{I}_{420-520} / \mathrm{I}_{580-680}\right)$ did not substantially affect the protein, fiber, moisture, and ash content of the algal biomass. However, as the ratio $\left(\mathrm{I}_{420-520} / \mathrm{I}_{580-680}\right)$ decreased, the NFE content decreased, while the lipid content increased from $12.7 \%$ at ratio 1.30 to $20.0 \%$ at ratio 0.30 . Lipid productivity was highest in the ratio 1.30 and lowest in the ratio 0.30 as a result of higher biomass productivity. Protein productivity declined as the $\mathrm{I}_{420-520} / \mathrm{I}_{580-680}$ ratio decreased because of decreased biomass productivity (Table 3). 
Table 4. Composition (\%) of C. vulgaris cultivated at four different ratios $\left(\mathrm{I}_{420-520} / \mathrm{I}_{580-680}\right)$ and at four different light intensities with white and red LED lamps in the closed bioreactor (in $\mu$ mol photons $\left.\mathrm{m}^{-2} \mathrm{~s}^{-1}\right)$.

\begin{tabular}{|c|c|c|c|c|c|c|}
\hline $\mathrm{I}_{420-520} / \mathrm{I}_{580-680}$ & Moisture & Lipids & Proteins & Ash & Fiber & NFE \\
\hline 1.30 & $8.067 \pm 0.252^{a}$ & $12.680 \pm 0.191^{d}$ & $26.710 \pm 0.274^{a}$ & $12.367 \pm 0.451^{a}$ & $9.267 \pm 0.252^{\mathrm{a}}$ & $30.910 \pm 0.476^{\mathrm{a}}$ \\
\hline 0.90 & $7.800 \pm 0.100^{\mathrm{a}}$ & $16.219 \pm 0.655^{c}$ & $25.509 \pm 0.141^{b}$ & $12.267 \pm 0.252^{a}$ & $9.467 \pm 0.250^{\mathrm{a}}$ & $28.738 \pm 0.725^{b}$ \\
\hline 0.60 & $7.867 \pm 0.351^{\mathrm{a}}$ & $18.447 \pm 0.436^{b}$ & $25.249 \pm 0.304^{b}$ & $12.333 \pm 0.473^{a}$ & $9.333 \pm 0.255^{\mathrm{a}}$ & $26.771 \pm 0.643^{b}$ \\
\hline 0.30 & $8.000 \pm 0.100^{a}$ & $19.984 \pm 0.439^{a}$ & $25.819 \pm 0.126^{b}$ & $12.217 \pm 0.225^{\mathrm{a}}$ & $9.433 \pm 0.252^{\mathrm{a}}$ & $24.547 \pm 0.839^{c}$ \\
\hline \multicolumn{7}{|l|}{$\begin{array}{c}\text { Light Intensity } \\
\text { (in } \mu \mathrm{mol} \text { Photons } \\
\mathrm{m}^{-2} \mathrm{~s}^{-1} \text { ) }\end{array}$} \\
\hline 520 & $8.000 \pm 0.265^{a}$ & $22.240 \pm 0.305^{a}$ & $25.741 \pm 0.122^{a}$ & $12.233 \pm 0.306^{\mathrm{a}}$ & $9.533 \pm 0.208^{a}$ & $22.252 \pm 0.469^{d}$ \\
\hline 390 & $7.700 \pm 0.200^{\mathrm{a}}$ & $14.696 \pm 0.307^{b}$ & $25.565 \pm 0.415^{a}$ & $12.250 \pm 0.391^{\mathrm{a}}$ & $9.333 \pm 0.153^{a}$ & $30.456 \pm 0.643^{c}$ \\
\hline 260 & $7.900 \pm 0.100^{a}$ & $10.948 \pm 0.306^{c}$ & $25.545 \pm 0.322^{a}$ & $12.400 \pm 0.400^{\mathrm{a}}$ & $9.300 \pm 0.265^{\mathrm{a}}$ & $33.907 \pm 0.221^{b}$ \\
\hline 130 & $8.100 \pm 0.100^{a}$ & $7.879 \pm 0.288^{\mathrm{d}}$ & $25.100 \pm 0.629^{a}$ & $12.200 \pm 0.300^{a}$ & $9.233 \pm 0.252^{\mathrm{a}}$ & $37.487 \pm 0.840^{\mathrm{a}}$ \\
\hline
\end{tabular}

Values represent averages \pm std. deviation $(n=9)$. Values in the same column followed by different superscript indicate statistically significant difference $(p<0.05)$.

A similar trend in lipid content was also observed as the artificial irradiation with white and red LED lamps in the bioreactor increased from $130 \mu \mathrm{mol}$ photons $\mathrm{m}^{-2} \mathrm{~s}^{-1}$ to $520 \mu \mathrm{mol}$ photons $\mathrm{m}^{-2} \mathrm{~s}^{-1}$. The NFE content decreased with the increase of light intensity, while the protein, moisture, fiber, and ash content were unaffected from the artificial irradiation in the bioreactor.

\subsection{Algal Growth Kinetic Model as a Function of Light Intensity}

Equation (5) after fitting the experimental data of Table 3 (that is the different artificial irradiations with white and red LED lamps in the bioreactor) becomes

$$
\mu=0.553 \frac{I}{275.116+I}, \mathrm{R}^{2}=0.99
$$

This model predicts that at sufficiently high $I$ values, $\mu$ becomes equal to $\mu_{\max }$, while at low $I$ values $\mu$ is proportional to the light intensity $I$.

\section{Discussion}

\subsection{Effect of Light Intensity on the Growth Rate of C. vulgaris}

Microalgae growth is affected by different factors [38], with light intensity being among the most important. Light is an essential source for microalgae autotrophic growth and the most important element for photosynthetic activity [39]. It contributes into cell multiplication, respiration and photosynthesis [40]. Microalgae require light to produce ATP and NADPH and synthesize essential molecules for growth [16]. The optimum light intensity for growth and biomass production varies in different microalgae species and depends on other factors as well, such as temperature and availability of nutrients in the culture medium [14]. Biomass production in microalgae species generally increases with increasing light intensity, which is due to the higher absorption and utilization of light by the photosynthetic apparatus. However, at high light intensities, beyond the saturation point, photo-inhibition is observed because of photo-oxidation reactions taking place inside the cell [41]. This saturation point depends on the particular algal species and the cultivation conditions.

In the present study, it was found that light intensity had a profound effect on growth of $C$. vulgaris and on biomass productivity. In the greenhouse experiments, the increase from $25 \%$ to $50 \%$ and to $100 \%$ in solar irradiance during June and September, led to consequent increases in specific growth rates in the exponential growth phase $\left(\mu_{\exp }\right)$, in maximum absorbance readings and in total biomass productivities. Faster growth rates for $C$. vulgaris under higher light intensities have also been reported by other researchers, such as Khoeyi et al. [41] and Seyfabadi et al. [42]. 
Similarly, in the closed laboratory bioreactor, it was shown that the ratio of light in the range of $420-520 \mathrm{~nm}$ to the light in the range of $580-680 \mathrm{~nm}\left(\mathrm{I}_{420-520} / \mathrm{I}_{580-680}\right)$ had a profound effect on the growth of $C$. vulgaris culture. The increase of ratio $\mathrm{I}_{420-520} / \mathrm{I}_{580-680}$ resulted in an increase in maximum absorbance and in total biomass productivity. Additionally, it was observed that as the ratio $\mathrm{I}_{420-520} / \mathrm{I}_{580-680}$ increased from 0.30 to 1.30 , the coefficient of the specific growth rate $\left(\mu_{\exp }\right)$ increased as well. This is probably due to the fact that in the $420-520 \mathrm{~nm}$ range, pigments (carotenoids) also absorb photons during photosynthesis and as accessory pigments they transfer part of the light intensity they absorb to the chlorophylls [43].

In the experiment studying the effect of artificial irradiation with white and red LED lamps in the bioreactor at a constant ratio $\left(\mathrm{I}_{420-520} / \mathrm{I}_{580-680}\right.$ equal to 0.90$)$, it was found that the increase of irradiation from $130 \mu \mathrm{mol}$ photons $\mathrm{m}^{-2} \mathrm{~s}^{-1}$, to 260 , to 390 , and to $520 \mu \mathrm{mol}$ photons $\mathrm{m}^{-2} \mathrm{~s}^{-1}$ resulted in faster growth rates as expressed by the increase in specific growth rates in the exponential growth phase $\left(\mu_{\text {exp }}\right)$. Additionally, maximum absorbance readings and total biomass productivities increased with the increase of irradiation.

Das et al. [44] found that the maximum growth rate of Nannochloropsis sp. was observed when cultivated at monochromatic blue light, followed by cultivation at white and last at red light. The highest biomass productions of $N$. salina, N. oceanica, and N. oculata were found in cultivation in blue light, followed by cultivation in red LED, fluorescent light, purple LED, yellow LED, and green LED [45]. In C. vulgaris, cultivation in blue monochromatic light at $475 \mathrm{~nm}$ resulted in higher growth rate and biomass production in comparison to cultivation at clear, red, and green light [46]. In another study, C. vulgaris grew best when cultivated under cool white light in comparison with cultivation at blue and red light [47]. It appears that the two studies differ in both the types of illumination (lamps) used as well as the configuration of illumination. Blair et al. [46] used CFL lamps which were placed outside the bioreactors at a distance of $20 \mathrm{~cm}$ providing light at $650 \mathrm{~nm}$ (red), $475 \mathrm{~nm}$ (blue), and clear white light but no mention of its spectral output intensity is given. On the other hand, Wong et al. [47] used LED lamps of $5300 \mathrm{~K}$ (white light), $457 \mathrm{~nm}$ (blue), and $660 \mathrm{~nm}$ (red) placed in the interior of the bioreactor. Therefore, it appears that differences observed in the growth rates in these two studies may be due to differences in the type of lamps used, their spectral and intensity characteristics as well as the illumination configuration.

According to Atta et al. [48], the growth rate of $C$. vulgaris increased when the light intensity with blue LED lamps increased from 100 to $200 \mu \mathrm{mol}$ photons $\mathrm{m}^{-2} \mathrm{~s}^{-1}$ at 12:12 $\mathrm{h}$ light: dark. However, further increase of light intensity to $300 \mu \mathrm{mol}$ photons $\mathrm{m}^{-2} \mathrm{~s}^{-1}$ resulted in a decrease in the growth rate. Although only three light intensities were examined, the authors state that the $200 \mu \mathrm{mol}$ photons $\mathrm{m}^{-2}$ $\mathrm{s}^{-1}$ represents the saturation limit while at $300 \mu \mathrm{mol}$ photons $\mathrm{m}^{-2} \mathrm{~s}^{-1}$ photo-inhibition is observed. Apparently increasing light intensity increases the growth rate because more light photons become available but, at higher light intensities photo-inhibition decreases the growth rate.

Some investigators have developed multivariable models to examine the effects on algal growth of a single substrate factor or considering multiple factors such as light intensity, temperature, nitrogen, phosphorus, and $\mathrm{CO}_{2}$. For example, Rubio et al. [49] developed a model to account for photo-adaptation, photo-inhibition, and the flashing light effect in microalgae. Blanken et al. [50] presented a kinetic model to predict light limited growth for Chlorella sorokiniana and Chlamydomonas reinhardtii. Takache et al. [51] developed a model to describe the relationship between the biomass productivity of Chlamydomonas reinhardtii and light, taking into account the photosynthesis and respiration that take place in this organism.

In this study, a Monod type saturation model (with respect to intensity) was used to fit the experimental data. From the experimental measurements the growth rate at low illumination values was nearly proportional to the light intensity. For light intensities higher than $260 \mu \mathrm{mol}$ photons $\mathrm{m}^{-2}$ $\mathrm{s}^{-1}$ this proportionality broke down. This model fitted accurately the experimental data in a wide range of light intensities and therefore, it could aid the optimization of the cultivation process and could provide a key for understanding and predicting the growth rate of $C$. vulgaris. This model has 
also been used successfully by Sasi et al. [52] to fit experimental data for C. vulgaris concerning the specific growth rate coefficient versus light intensity. It predicts that at near zero light intensity the specific rate coefficient is proportional to the light intensity and at high light intensities it becomes independent of light intensity and equal to $\mu_{\max }$. No photo-inhibition, that is reduction of the growth rate, was observed for the intensity range of the study.

\subsection{Effect of Light Intensity on Composition of C. vulgaris}

\subsubsection{Experiments in the Greenhouse}

As far as the composition of the biomass produced in the greenhouse is concerned, it was found that solar irradiance did not substantially affect the protein, fiber, moisture, and ash content of the algal biomass. On the other hand, the lipid content of the biomass of $C$. vulgaris and the NFE content were dependent on the light intensity in both environmental conditions (June and September). Specifically, the lipid content of the biomass of C. vulgaris increased from 19.5\% (at 25\% solar irradiance) to $25.6 \%$ (at 100\% solar irradiance) at cultivation during June and from $17.3 \%$ (at $25 \%$ solar irradiance) to $24.7 \%$ (at 100\% solar irradiance) at cultivation during September. The NFE content decreased as the solar irradiance increased from $25 \%$ to $100 \%$ in both experimental conditions.

It is known that adequate light intensity favors the overproduction of microalgae lipids, possibly because sufficient light intensity is beneficial to the storage of excess photoassimilates, which are further converted into chemical energy [53]. Lipid, and especially triacylglycerol synthesis, requires excess ATP and NADPH which are produced by the photosynthesis process. When excess energy in the form of photons is supplied, more lipids can be synthesized, in which case they utilize this excess energy and therefore protect the algal cells from photochemical damage [54]. Therefore, as shown in Table 2, when photon flux is increased, more carbon produced from the photosynthesis is used towards lipid production.

Similar findings have been reported for other microalgae species, such as for the marine microalga species Odontella aurita, in which cultivation in increased light intensity resulted in higher lipid content, but it had no significant effect on the protein content [55]. Other studies in Chlorella sp. indicated that the increase of light intensity resulted in higher lipid, as reported by He et al. [27], while according to Seyfabadi et al. [42], increased light intensity resulted in increased protein concentration in C. vulgaris. It should be mentioned that He et al. [27] used continuous illumination, without a dark period, of 40, 200, and $400 \mu \mathrm{mol}$ photons $\mathrm{m}^{-2} \mathrm{~s}^{-1}$ using a daylight fluorescent lamp, while Seyfabadi et al. [42] performed their study at 37.5, 62.5, and $100 \mu \mathrm{mol}$ photons $\mathrm{m}^{-2} \mathrm{~s}^{-1}$ irradiance and 8:16, 12:12, and 16:8 $\mathrm{h}$ (light/dark) cycles.

\subsubsection{Experiments in the Closed Bioreactor-Effect of Wavelength and Artificial Irradiation}

In the experiments conducted in the bioreactor, the increase of ratio of light in the range of $420-520 \mathrm{~nm}$ to light in the range of 580-680 $\mathrm{nm}\left(\mathrm{I}_{420-520} / \mathrm{I}_{580-680}\right)$ resulted in a decrease in lipid content from $20.0 \%$ at ratio 0.30 to $12.7 \%$ at ratio 1.30 and an increase of NFE content. The protein, fiber, moisture and ash content of the algal biomass were not affected appreciably by the ratio $\mathrm{I}_{420-520} / \mathrm{I}_{580-680}$.

Lipid productivity was highest in the ratio 1.30 and lowest in the ratio 0.30 as a result of higher biomass productivity. Protein content was basically unaffected by the ratio $\mathrm{I}_{420-520} / \mathrm{I}_{580-680}$ ratio but its productivity declined as the ratio $\mathrm{I}_{420-520} / \mathrm{I}_{580-680}$ ratio decreased because of decreased biomass productivity in 0.30 ratio. In this study, biomass was collected at the same cultivation time in order to compare lipid content and productivity since the lipid content varies with cultivation time. It thus appears from this study, as well as from other relevant studies in literature that the lipid and protein content of $C$. vulgaris and the biomass productivity are affected both by the wavelength of light as well as by the algal biomass collection time, whether this is done before, during or past the stationary growth phase $[25,47]$. Also, reactor and illumination configuration may affect biomass, protein, and lipid productivities [56]. 
According to Wong et al. [47], C. vulgaris had the highest lipid content when cultivated with blue light (LED lamp), although white light gave similar results. Lipid content increased as a function of cultivation time reaching its maximum value after 10 days at the end of the cultivation period. The highest growth rate and biomass production was observed when cultivated with white color and as a result, the maximum lipid productivity was observed when cultivated with white light.

Zhang et al. [57] studied the effect of light wavelength using LED lamps (red, white, blue) on the lipid content of $C$. vulgaris. They found that the maximum lipid content was obtained when cultivated with blue light (31.2\%), followed by red light (20.5\%) and last white light (19.3\%). It should be mentioned that the blue LED lamp spectrum used in that study [57] extends well below $400 \mathrm{~nm}$, where both chlorophylls absorb, while the white LED lamp, also used in the present study to provide the blue light, emits only above $420 \mathrm{~nm}$. Similarly, Atta et al. [48] found that the lipid content of C. vulgaris increased when the light intensity with blue LED lamps increased from 100 to $200 \mu \mathrm{mol}$ photons $\mathrm{m}^{-2} \mathrm{~s}^{-1}$ at 12:12 $\mathrm{h}$ light: dark. Gaytán-Luna et al. [58] studied the effect of green, white, and red light on the lipid content of Chlamydomonas reinhardtii. They found that the maximum lipid content was observed when cultivated at red light in comparison with cultivation at white and green light. The blue light affects the activation of enzymes activity (Ribulose bisphosphate carboxylase/oxygenase and carbonic anhydrase) [48]. Additionally, the exposure of microalgae to pure red light can cause cell damage, which can be repaired by low exposure of microalgae to blue light [44]. Contributing factor to the lipid accumulation may be the shift from the natural wavelength distribution which may be acting as a stress factor.

As far as the protein content of $C$. vulgaris is concerned, it appears that the increase in ratio $\mathrm{I}_{420-520} / \mathrm{I}_{580-680}$ did not follow the same trend with the lipid content, as it was similar $(p<0.05)$ in the different light intensities. This may be due to the fact that the protein is a significant structural and metabolic component of algal cells, so that their protein content might be more resistant to alterations of light intensity. Additionally, it is known that the protein content is affected more by nitrogen concentration, as nitrogen is required for protein-synthesis and the nitrogen concentration of the culture medium was the same in all experimental trials [25]. Nitrogen is used during the exponential growth phase preferably for biomass production and protein synthesis. At the end of the exponential growth phase (stationary phase) nitrogen is depleted and further cultivation results in lipid accumulation as more carbon is supplied with air as $\mathrm{CO}_{2}$. At all light intensity ratios, the harvesting of biomass was performed at the same time (at the end of the exponential growth phase). Therefore, at the end of the exponential growth phase protein content should be about the same in all light ratios.

Kendirlioglu and Cetin [59] studied the growth rate and protein amount of $C$. vulgaris cultivated at different wavelengths of light (blue, red and white light). They found that the highest growth and amount of protein were in cultures illuminated with red light, followed by white light and then blue. Asuthkar et al. [60] studied the effect of light wavelength (blue, white, red LED lamps) on the growth rate and protein content of Chlorella pyrenoidosa. They found that the specific growth rate was highest when using blue light $\left(\mu=0.51 \mathrm{~d}^{-1}\right)$, followed by white light $\left(\mu=0.24 \mathrm{~d}^{-1}\right)$ and red light $\left(\mu=0.22 \mathrm{~d}^{-1}\right)$. Protein content was also highest in blue light, followed by red light and was lowest when white light was used.

In the experiments where the artificial irradiation with white and red LED lamps at a constant ratio (ratio $\mathrm{I}_{420-520} / \mathrm{I}_{580-680}$ equal to 0.90 ) was studied, it was found that as the irradiation increased from $130 \mu \mathrm{mol}$ photons $\mathrm{m}^{-2} \mathrm{~s}^{-1}$ to $520 \mu \mathrm{mol}$ photons $\mathrm{m}^{-2} \mathrm{~s}^{-1}$, the lipid content increased from $7.9 \%$ to $22.2 \%$, the NFE content decreased and the protein, fiber, moisture and ash content were unaffected. According to Wong et al. [47], higher light intensity resulted in higher lipid productivity in C. vulgaris, because the production of storage lipids (triglycerides) acts as a protective mechanism for the cells to prevent further damage from photo-oxidation caused by very high light intensities.

Examining the effect of wavelength on biomass and lipid productivities, the present study agrees with relevant studies in the literature mentioned above, but finds that lipid content increases as the wavelength shifts towards the red from $12.7 \%$ at ratio $\mathrm{I}_{420-520} / \mathrm{I}_{580-680}$ equal to 1.30 to $20.0 \%$ at ratio 
$\mathrm{I}_{420-520} / \mathrm{I}_{580-680}$ equal to 0.30 . Blue LED lamps which were used in other studies emit below $420 \mathrm{~nm}$, which is the lowest wavelength used in this study. It should be mentioned that although the light spectrum of sunlight and the laboratory bioreactor LED lamps are not the same, the former emitting below $420 \mathrm{~nm}$, where chlorophylls a and b absorb, this study shows that the trend in biomass, lipid, and protein productivities as a function of intensity are similar in the two systems.

\section{Conclusions}

The light intensity and wavelength strongly affected the growth of $C$. vulgaris as well as its biomass nutrient composition. In the experiments conducted in the greenhouse, the specific growth rate in the exponential growth phase $\left(\mu_{\exp }\right)$ and the total biomass productivity attained at the end of the cultivation increased with the increase of solar irradiance from $25 \%$ to $100 \%$ both in June and September. In the experiments conducted in the closed bioreactor, as the ratio $\mathrm{I}_{420-520} / \mathrm{I}_{580-680}$ increased, the specific growth rate and the total biomass production increased as well. Additionally, the increase in intensity with white and red LED lamps (from 130 to $520 \mu \mathrm{mol}$ photons $\mathrm{m}^{-2} \mathrm{~s}^{-1}$ ) led to faster growth rates.

As far as the composition of the biomass produced is concerned, in the greenhouse the lipid content of C. vulgaris increased (up to $25.6 \%$ in June and $24.7 \%$ in September) with the increase of solar irradiance and the NFE content decreased in both environmental conditions. On the other hand, the protein, fiber, moisture, and ash content of the algal biomass did not change significantly with the increase in solar irradiance. In the experiments conducted in the closed bioreactor, the increase of ratio $\mathrm{I}_{420-520} / \mathrm{I}_{580-680}$ (from 0.30 to 1.30) resulted in a decrease in lipid content (from $20.0 \%$ to $12.7 \%$ respectively) and an increase of NFE content, while the protein, fiber, moisture and ash content of the algal biomass were not affected significantly by the ratio $\mathrm{I}_{420-520} / \mathrm{I}_{580-680}$. Additionally, as the irradiation with white and red LED lamps increased (from 130 to $520 \mu \mathrm{mol}$ photons $\mathrm{m}^{-2} \mathrm{~s}^{-1}$ ), the lipid content increased significantly (from $7.9 \%$ to $22.2 \%$ respectively), while the NFE content decreased and the protein, fiber, moisture, and ash content were unaffected.

Author Contributions: Conceptualization, G.P., I.T.K. and N.K.; Data curation, M.N.M.; Funding acquisition, N.K.; Investigation, M.N.M.; Methodology, G.P.; Project administration, N.K.; Supervision, N.K.; Writing-original draft, M.N.M.; Writing - review \& editing, G.P., I.T.K. and N.K. All authors have read and agreed to the published version of the manuscript.

Funding: This research has been co-financed by the European Union and Greek national funds through the Operational Program Competitiveness, Entrepreneurship and Innovation, under the call RESEARCH-CREATE-INNOVATE (project code: T1EDK-01580). Maria Metsoviti (PhD student) would like to thank the Onassis Foundation in Greece for the scholarship awarded for her PhD study.

Conflicts of Interest: The authors declare no conflict of interest.

\section{References}

1. Mata, T.M.; Martins, M.M.; Caetano, N.S. Microalgae for biodiesel production and other applications: A review. Renew. Sustain. Energy Rev. 2010, 14, 217-232. [CrossRef]

2. Chojnacka, K.; Marquez-Rocha, F.-J. Kinetic and stoichiometric relationships of the energy and carbon metabolism in the culture of microalgae. Biotechnology 2004, 3, 21-34.

3. Spolaore, P.; Joannis-Cassan, C.; Duran, E.; Isambert, A. Commercial applications of microalgae. J. Biosci. Bioeng. 2006, 101, 87-96. [CrossRef] [PubMed]

4. Borowitzka, M.A. High-value products from microalgae-Their development and commercialisation. J. Appl. Phycol. 2013, 25, 743-756. [CrossRef]

5. Yeo, U.; Lee, I.; Seo, I.; Kim, R. Identification of the key structural parameters for the design of a large-scale PBR. Biosyst. Eng. 2018, 171, 165-178. [CrossRef]

6. Adarme-Vega, T.C.; Lim, D.K.Y.; Timmins, M.; Vernen, F.; Li, Y.; Schenk, P.M. Microalgal biofactories: A promising approach towards sustainable omega-3 fatty acid production. Microb. Cell Factories 2012, 11, 96. [CrossRef] [PubMed] 
7. Aramrueang, N.; Rapport, J.; Zhang, R. Effects of hydraulic retention time and organic loading rate on performance and stability of anaerobic digestion of Spirulina platensis. Biosyst. Eng. 2016, 147, 174-182. [CrossRef]

8. Chen, J.; Dong, W.; Zhang, X.; Tyagi, R.D.; Drogui, P.; Surampalli, R.D. The potential of microalgae in biodiesel production. Renew. Sustain. Energy Rev. 2018, 90, 336-346. [CrossRef]

9. Barsanti, L.; Gualtieri, P. Algal culturing. In Algae: Anatomy, Biochemistry, and Biotechnology Taylor and Francis, 1st ed.; CRC Press: Boca Raton, FL, USA, 2006.

10. Pulz, O. Photobioreactors: Production systems for phototrophic microorganisms. Appl. Microbiol. Biotechnol. 2001, 57, 287-293. [CrossRef]

11. Seo, I.; Lee, I.; Hwang, H.; Hong, S.; Bitog, J.P.; Kwon, K.; Lee, C.; Kim, Z.; Cuello, J. Numerical investigation of a bubble-column photo-bioreactor design for microalgae cultivation. Biosyst. Eng. 2012, 113, $229-241$. [CrossRef]

12. Rösch, C.; Posten, C. Challenges and Perspectives of Microalgae Production; Karlsruhe Institute of Technology (KIT): Karlsruhe, Germany, 2012; p. 5.

13. Metsoviti, M.N.; Papapolymerou, G.; Karapanagiotidis, I.T.; Katsoulas, N. Comparison of growth rate and nutrient content of five microalgae species cultivated in greenhouses. Plants 2019, 8, 279. [CrossRef] [PubMed]

14. Li, Y.; Zhou, W.; Hu, B.; Min, M.; Chen, P.; Ruan, R.R. Effect of light intensity on algal biomass accumulation and biodiesel production for mixotrophic strains Chlorella kessleri and Chlorella protothecoide cultivated in highly concentrated municipal wastewater. Biotechnol. Bioeng. 2012, 109, 2222-2229. [CrossRef] [PubMed]

15. Xu, Y.; Ibrahim, I.M.; Harvey, P.J. The influence of photoperiod and light intensity on the growth and photosynthesis of Dunaliella salina (chlorophyta) CCAP 19/30. Plant Physiol. Biochem. 2016, 106, 305-315. [CrossRef] [PubMed]

16. Singh, S.P.; Singh, P. Effect of temperature and light on the growth of algae species: A review. Renew. Sustain. Energy Rev. 2015, 50, 431-444. [CrossRef]

17. Difusa, A.; Talukdar, J.; Kalita, M.C.; Mohanty, K.; Goud, V.V. Effect of light intensity and pH condition on the growth, biomass and lipid content of microalgae Scenedesmus species. Biofuels 2015, 6, 37-44. [CrossRef]

18. Lee, E.; Jalalizadeh, M.; Zhang, Q. Growth kinetic models for microalgae cultivation: A review. Algal Res. 2015, 12, 497-512. [CrossRef]

19. Minhas, A.K.; Hodgson, P.; Barrow, S.J.; Adholeya, A. A review on the assessment of stress conditions for simultaneous production of microalgal lipids and carotenoids. Front. Microbiol. 2016, 7, 546. [CrossRef]

20. Wijffels, R.H.; Barbosa, M.J.; Eppink, M.H.M. Microalgae for the production of bulk chemicals and biofuels. Biofuels Bioprod. Bioref. 2010, 4, 287-295. [CrossRef]

21. Chávez-Fuentes, P.; Ruiz-Marin, A.; Canedo-López, Y. Biodiesel synthesis from Chlorella vulgaris under effect of nitrogen limitation, intensity and quality light: Estimation on the based fatty acids profiles. Mol. Biol. Rep. 2018, 45, 1145-1154. [CrossRef]

22. Khalili, A.; Najafpour, G.D.; Amini, G.; Samkhaniyani, F. Influence of nutrients and LED light intensities on biomass production of microalgae Chlorella vulgaris. Biotechnol. Bioprocess Eng. 2015, 20, 284-290. [CrossRef]

23. Liu, Z.Y.; Wang, G.C.; Zhou, B.C. Effect of iron on growth and lipid accumulation in Chlorella vulgaris. Bioresour. Technol. 2008, 99, 4717-4722. [CrossRef] [PubMed]

24. Gouveia, L.; Oliveira, A.C. Microalgae as a raw material for biofuels production. J. Ind. Microbiol. Biotechnol. 2009, 36, 269-274. [CrossRef] [PubMed]

25. Metsoviti, M.N.; Katsoulas, N.; Karapanagiotidis, I.T.; Papapolymerou, G. Effect of nitrogen concentration, two-stage and prolonged cultivation on growth rate, lipid and protein content of Chlorella vulgaris. J. Chem. Technol. Biotechnol. 2019, 94, 1466-1473. [CrossRef]

26. George, B.; Pancha, I.; Dessai, C.; Chokshi, K.; Paliwal, C.; Ghosh, T.; Mishra, S. Effects of different media composition, light intensity and photoperiod on morphology and physiology of freshwater microalgae Ankistrodesmus falcatus-A potential strain for bio-fuel production. Bioresour. Technol. 2014, 171, 367-374. [CrossRef]

27. He, Q.; Yang, H.; Wu, L.; Hu, C. Effect of light intensity on physiological changes, carbon allocation and neutral lipid accumulation in oleaginous microalgae. Bioresour. Technol. 2015, 191, 219-228. [CrossRef]

28. Ruangsomboon, S. Effect of light, nutrient, cultivation time and salinity on lipid production of newly isolated strain of the green microalga, Botryococcus braunii KMITL 2. Bioresour. Technol. 2012, 109, 261-265. [CrossRef] 
29. Baiee, M.A.; Salman, J.M. Effect of phosphorus concentration and light intensity on protein content of microalga Chlorella vulgaris. Mesop. Environ. J. 2016, 2, 75-86.

30. SAG. Sammlung von Algenkulturen der Universität Göttingen. Culture Collection of Algae, Abteilung Experimentelle Phykologie und Sammlung von Algenkulturen (EPSAG), Universität Göttingen, Deutschland. 2007. Available online: http://epsag.uni-goettingen.de (accessed on 4 November 2019).

31. Chen, C.Y.; Yeh, K.L.; Aisyah, R.; Lee, D.J.; Chang, J.S. Cultivation, photobioreactor design and harvesting of microalgae for biodiesel production: A critical review. Bioresour. Technol. 2011, 102, 71-81. [CrossRef]

32. Perez, L.; Salgueiro, J.L.; Maceiras, R.; Cancela, A.; Sanchez, A. An effective method for harvesting of marine microalgae: $\mathrm{pH}$ induced flocculation. Bioresour. Technol. 2017, 97, 20-26. [CrossRef]

33. Safi, C.; Zebib, B.; Merah, O.; Pontalier, P.Y.; Vaca-Garcia, C. Morphology, composition, production, processing and applications of Chlorella vulgaris: A review. Renew. Sustain. Energy Rev. 2014, 35, 265-278. [CrossRef]

34. Association of Official Analytical Chemists (AOAC). Official Methods of Analysis of the Association of Official Analytical Chemists International, 16th ed.; AOAC: Arlington, VA, USA, 1995.

35. Biancarosa, I.; Espe, M.; Bruckner, C.G.; Heesch, S.; Liland, N.; Waagbø, R.; Torstensen, B.; Lock, E.J. Amino acid composition, protein content, and nitrogen-to-protein conversion factors of 21 seaweed species from Norwegian waters. J. Appl. Phycol. 2017, 29, 1001-1009. [CrossRef]

36. Folch, J.; Lees, M.; Sloane-Stanley, G.H. A simple method for the isolation and purification of total lipides from animal tissues. J. Biol. Chem. 1957, 226, 497-509. [PubMed]

37. Ryckebosch, E.; Muylaert, K.; Foubert, I. Optimization of an analytical procedure for extraction of lipids from microalgae. J. Am. Oil Chem. Soc. 2012, 89, 189-198. [CrossRef]

38. Dean, A.; Sigee, D.; Estrada, B.; Pittman, J. Using FTIR spectroscopy for rapid determination of lipid accumulation in response to nitrogen limitation in freshwater microalgae. Bioresour. Technol. 2010, 101, 4499-4507. [CrossRef] [PubMed]

39. Sharma, R.; Singh, G.P.; Sharma, V.K. Effects of culture conditions on growth and biochemical profile of Chlorella vulgaris. J. Plant Pathol. Microb. 2012, 3, 5. [CrossRef]

40. Daliry, S.; Hallajisani, A.; Mohammadi, R.J.; Nouri, H.; Golzary, A. Investigation of optimal condition for Chlorella vulgaris microalgae growth. Glob. J. Environ. Sci. Manag. 2017, 3, 217-230. [CrossRef]

41. Khoeyi, Z.A.; Seyfabadi, J.; Ramezanpour, Z. Effect of light intensity and photoperiod on biomass and fatty acid composition of the microalgae, Chlorella vulgaris. Aquac. Int. 2010, 20, 41-49. [CrossRef]

42. Seyfabadi, J.; Ramezanpour, Z.; Khoeyi, Z.A. Protein, fatty acid, and pigment content of Chlorella vulgaris under different light regimes. J. Appl. Phycol. 2011, 23, 721-726. [CrossRef]

43. Lichtenthaler, H.K. Chlorophylls and carotenoids: Pigments of photosynthetic biomembranes. Methods Enzymol. 1987, 148, 350-383. [CrossRef]

44. Das, P.; Lei, W.; Aziz, S.S.; Obbar, S. Enhanced algae growth in both phototrophic and mixotrophic culture under blue light. Bioresour. Technol. 2011, 102, 3883-3887. [CrossRef]

45. Ra, C.H.; Kang, C.H.; Jung, J.H.; Jeong, G.T.; Kim, S.K. Effects of light-emitting diodes (LEDs) on the accumulation of lipid content using a two-phase culture process with three microalgae. Bioresour. Technol. 2016, 212, 254-261. [CrossRef] [PubMed]

46. Blair, M.F.; Kokabian, B.; Gude, V.G. Light and growth medium effect on Chlorella vulgaris biomass production. J. Environ. Chem. Eng. 2014, 2, 665-674. [CrossRef]

47. Wong, Y.K.; Ho, Y.H.; Ho, K.C.; Leung, H.M.; Chow, K.P.; Yung, K.K.L. Effect of different light sources on algal biomass and lipid production in internal Leds-illuminated photobioreactor. J. Mar. Biol. Aquac. 2016, 2, 1-8. [CrossRef]

48. Atta, M.; Idris, A.; Bukhari, A.; Wahidin, S. Intensity of blue LED light: A potential stimulus for biomass and lipid content in fresh water microalgae Chlorella vulgaris. Bioresour. Technol. 2013, 148, 373-378. [CrossRef] [PubMed]

49. Rubio, F.C.; Camacho, F.G.; Sevilla, J.M.F.; Chisti, Y.; Grima, E.M. A mechanistic model of photosynthesis in microalgae. Bioresour. Technol. 2002, 81, 459-473. [CrossRef] [PubMed]

50. Blanken, W.; Postma, P.R.; Winter, L.; Wijffels, R.H.; Janssen, M. Predicting microalgae growth. Algal Res. 2016, 14, 28-38. [CrossRef]

51. Takache, H.; Pruvost, J.; Cornet, J.F. Kinetic modeling of the photosynthetic growth of Chlamydomonas reinhardtii in a photobioreactor. Biotechnol. Prog. 2012, 28, 681-692. [CrossRef] [PubMed] 
52. Sasi, D.; Mitra, P.; Vigueras, A.; Hill, G.A. Growth kinetics and lipid production using Chlorella vulgaris in a circulating loop photobioreactor. J. Chem. Technol. Biotechnol. 2011, 86, 875-880. [CrossRef]

53. Solovchenko, A.E.; Khozin-Goldberg, I.; Didi-Cohen, S.; Cohen, Z.; Merzlyak, M.N. Effects of light intensity and nitrogen starvation on growth, total fatty acids and arachidonic acid in the green microalga Parietochloris incisa. J. Phycol. 2008, 20, 245-251. [CrossRef]

54. Liu, J.; Yuan, C.; Hu, G.; Li, F. Effects of light intensity on the growth and lipid accumulation of microalga Scenedesmus sp. 11-1 under nitrogen limitation. Appl. Biochem. Biotechnol. 2012, 166, 2127-2137. [CrossRef]

55. Xia, S.; Wan, L.; Li, A.; Sang, M.; Zhang, C. Effects of nutrients and light intensity on the growth and biochemical composition of a marine microalga Odontella aurita. Chin. J. Oceanol. Limnol. 2013, 3, 1-6. [CrossRef]

56. Pruvost, J.; Vooren, G.V.; Gouic, B.L.; Couzinet-Mossion, A.; Legrand, J. Systematic investigation of biomass and lipid productivity by microalgae in photobioreactors for biodiesel application. Bioresour. Technol. 2011, 102, 150-158. [CrossRef] [PubMed]

57. Zhang, Y.; Dong, F.; Jin, P. Effects of Light-emitting Diodes (LEDs) on the Accumulation of Lipid Content in Microalgae. In Proceedings of the 2nd International Conference on Sustainable Energy and Environment Protection (ICSEEP 2017), Changsha, China, 23-25 June 2017. [CrossRef]

58. Gaytan-Luna, D.E.; Ochoa-Alfaro, A.E.; Rocha-Uribe, A. Effect of green and red light in lipid accumulation and transcriptional profile of genes implicated in lipid biosynthesis in Chlamydomonas reinhardtii. Biotechnol. Prog. 2016, 32, 1404-1411. [CrossRef] [PubMed]

59. Kendirlioglu, G.; Cetin, A.K. Effect of different wavelengths of light on growth, pigment content and protein amount of Chlorella vulgaris. Fresenius Environ. Bull. 2017, 26, 7974-7980.

60. Asuthkar, M.; Gunti, Y.; Ramgopal, R.S.; Rao, C.S.; Yadavalli, R. Effect of different wavelengths of light on the growth of Chlorella pyrenoidosa. Int. J. Pharm. Sci. Res. 2016, 7, 847-851. [CrossRef]

(C) 2019 by the authors. Licensee MDPI, Basel, Switzerland. This article is an open access article distributed under the terms and conditions of the Creative Commons Attribution (CC BY) license (http://creativecommons.org/licenses/by/4.0/). 